\title{
The Moderate Philanthropymodel And Its Effect On Pluralism And Deradicalization
}

\author{
M S Mauludin ${ }^{1}$, Z Soimah ${ }^{2}$ \\ IAIN Kediri, Jl. SunanAmpel 7 Ngronggo, Kediri ${ }^{1}$ \\ IAIN Kediri, Jl. SunanAmpel 7 Ngronggo, Kediri1 ${ }^{2}$ \\ \{msolehmauludin@iainkediri.ac.id ${ }^{1}$, zakiyatus.soimah@iainkediri.ac.id ${ }^{2}$ \}
}

\begin{abstract}
Islamic philanthropy, which includes infaq and sadaqah, is not only an embodiment of Islamic values but also an effective medium in fostering pluralism and deradicalization. This research aims to see the impacts of philanthropy movement on the construction of livable housing, carried out independently by the disciples of Shiddiqiyah Tariqa in Ploso, Jombang, Kediri. In only two years (2017-2018), they had built 54 units of livable housing, 10 of which were conducted by non-Muslim communities. This study uses a qualitative method with an ethnographic approach, presenting a philanthropic culture in the process of livable housing construction carried out by the ShiddiqiyahTariqa. The result of this research indicates that the philanthropy movement carried out by the ShiddiqiyahTariqa's disciples has been able to increase the values of pluralism and deradicalization among their group members.
\end{abstract}

Keywords: Islamic Philanthropy, Pluralism, Deradicalization

\section{Introduction}

Islamic philanthropy, with all its forms such as zakat, infaq, alms, and waqf, has impacts on many aspects of life. Islamic philanthropy, which has a distinctive feature of economic activity because of the ownership rights transferred from one individual to another, does not only have an impact on the economic side but also on the individual's attitudes and behaviors. One of them is tolerance for other individuals who have different beliefs and ideologies. In the present context, it is more known with the concept of pluralism.

Pluralism is an idea or view that recognizes diversity in people [1]. Pluralism is an embodiment of attitudes that accept differences and heterogeneity as a necessity in society [2]. The pluralism that has been developed and made as the basis of analysis in Islamic theology and history refers to an active involvement in diversity and differences to build a common civilization. In this sense, pluralism does not only recognize plurality and difference but also actively assembles them for a higher social purpose, i.e. togetherness in building civilization. NurcholisMadjid said, "Pluralism is understood as the true link of diversity in the bonds of civilization" [3].

Pluralism must be positive and accompanied by harmony among religious communities. Pluralism has to include two principles: the first is that every religious person must have an understanding that there are other religions. The second is that he or she must commit to obey 
his or her own religion. Especially for Muslims, they have to be able to practice Islam in an inclusive manner under different models of paradigm [4].

Pluralism is closely related to deradicalization. If someone understands and appreciates pluralism, it can be assured that he or she also has a certain level of understanding of deradicalization. Deradicalization in religious understanding can be defined as a process to neutralize radical ideologies adopted by religious militants in justifying extremes and violence through Islamic da'wah. The term 'radical' in this context is pejorative in the sense that it accepts violence to whoever considered as an enemy and a threat the Islam, or the so-called radical groups [5]. Being an antithesis of radicalization, deradicalization is characterized by tolerance, inclusiveness, and moderation [6]. Tolerance holds an important role in deradicalization programs, and it can be developed through learning and habituation (learning habits). This learning process will run more quickly and productively if supported by environments, such as family or association [7].

A waqf fund-based Islamic boarding schools and madrasah play a very important role in reducing radicalism. The curriculum structure, which includes subject curriculum, correlated curriculum, integrated curriculum, core or intra curriculum, and extra-curriculum, is meant to build a tolerance-based character education [8]. The practice of channeling philanthropic funds to the minorities (ex-Gafatar) has many benefits, be it economical, social, and spiritual. Philanthropy is not just a symbol of charity, but also a bearer of social justice and deradicalization efforts. First, philanthropy for the ex-Gafatar helped them resolve their economic disparity by providing business capital assistance. Second, the philanthropy created a social justice by organizing socialization and seminars through which the ex-Gafatar can mingle with society. Third, philanthropic assistance for the ex-Gafatar is also useful to implement deradicalization. This is evidence that philanthropy is of importance for minority groups who need help to restore their confidence to continue their life, besides fulfilling their financial needs. This research is expected to enrich references in the management of philanthropic institutions in Indonesia, especially for minorities [6].

The above explanation implies that philanthropy is linked with attitude and pluralism in society. Amania's research focused on philanthropy distributed through waqf of an educational institution whose curriculum contains a deradicalization concept. Meanwhile, research by Nurul addressed philanthropy for communities exposed to radicalism, which this case is the ex-Gravatar. Unlike these two studies, this current research takes a different aspect. It will examine to what extent philanthropy has impacts on fostering pluralism and deradicalization among the subjects, i.e, the members of ShiddiqiyahTariqa.

\section{Method}

This research is qualitative with an ethnographic approach. This approach focuses on developing a complex and complete description of a culture within a similar cultural group. The group has interacted for a long time to establish a clear work pattern [9].

The context of this study is ShiddiqiyahTariqa that has a distinctive culture in philanthropy, namely the construction of livable houses for the poor. They donate their property, energy, and thoughts to build livable homes regardless of the background of the poor people for whom the houses are built. Poor people might be from different Islamic cultures or even other religions. The ethnographic approach that the authors used is realist ethnography, which refers to ethnographic reports objectively obtained from the participants. In this approach, the author made clear the positions of being an impartial third person and reported on what was observed or heard from the participants without being contaminated by personal interests and political 
considerations. The author captured objectively the philanthropic culture in building livable houses carried out by ShiddiqiyahTariqa, starting from the first process until the impacts appeared from this movement, especially on pluralism attitude among its group members.

The data was collected through a purposive sampling approach. The selected participants represent all occupations in the ShiddiqiyahTariqa, ranging from administrators, members, volunteers, and sympathizers with a total of 1,200 people in the Kediri district. The volunteers here are the management or members who involved in the process of building livable houses. The data collected in the form of a) observation, wherein the author was also participating in building livable houses;b) interviews, conducted by an open interview model, c) documents, where the author collected archived documents owned by the administrators of ShiddiqiyahTariqa; d) audiovisual materials, which include photos archives owned by the administrators. The author followed six stages in data analysis. The first step was processing and preparing data for analysis. The second was reading the entire data. The third was analyzing in more detail by coding the data. The fourth was applying the coding process to describe the settings, people, categories, and themes that will be analyzed. The fifth was presenting a description theme in a narrative. The sixth was interpreting data [10].

\section{Result and Discussion}

The construction of livable houses is entirely carried out independently by the members of ShiddiqiyahTariqa.The process started when the members got information on the presence of a poor whose house is unlivable. The member who knows this information will inform the branch manager. Based on the available information, the branch manager will survey the poor to determine eligibility. The criteria of the poor whose house will be reconstructed is economically poor and the house is physically not livable.

The administrators do not take into account the ideological and religious backgrounds of the poor. From 54 livable houses that have been built in 3 years, there are only two belonging to the members of ShiddiqiyahTariqa. The other ten units are owned by non-Muslim, and the rest are Muslims who neither a member nor a sympathizer of the ShiddiqiyahTariqa. This composition implies that the motivation of ShiddiqiyahTariqa in the livable house program is not to spread Islamic or its own ideology, rather purely humanitarian. They argued that the people economically incapable of unlivable houses should be helped for a more decent life. This is a moral message about humanity.

Conceptually, the Qur'an from the beginning has confirmed its transformative and liberating vision for humanity. Since it first came down to the earth through the revelation brought by the angel of Gabriel to the Prophet Muhammad, Islam has carried out a theological revolution against the theological tendencies of the Arabs who at that time worshipped idols around the Ka'bah. The theological revolution brought by the Prophet Muhammad emphasized the principle of monotheism (tauhid) which only recognizes the oneness of Allah Swt., and negated all the worshipping other than Allah Swt [11]. This implies that in monotheism there is a principle of equal humanity as a symbol of resistance to the practice of repression that happened before the messenger of Allah was sent [12]. Thus, it can be said that Islam since the beginning emphasizes the appreciation for people and encourages them to commit to human values [11].

Before the construction process is started, the ShiddiqiyahTariqa administrators will visit the local apparatus to give a notification. With such a model of communication pattern, it creates harmony between ShiddiqiyahTariqa and the surrounding communities. There were also cases when some members of the surrounding contribute their assets and energy. The 
construction process begins with providing the material on a shift basis, meaning that the available materials are not until 100 percent. The building materials were donated by the members of jama'ah independently and on average worth more than 60 million Rupiahs. The building construction process is carried out entirely by the volunteers with a shift model day and night. They do not only contribute their own energy but also come by loading building materials. Usually, the construction process is completed in a month. A decent house has a standard like a house in general. Usually, it is a 45 type-model with one living room, one family room, two bathrooms, and one kitchen.

Table 1. List of livable housing construction program:

\begin{tabular}{|c|c|c|c|}
\hline No & Name & Religion & Address \\
\hline 1 & Aminatun & Islam & Ds. Mlancu, Kec. Kandangan \\
\hline 2 & Zulaikah & Islam & Ds. Joho, Kec. Wates \\
\hline 3 & M. Ja'far & Islam & DsnSuwaru, Ds. Damarwulan, Kec. Kepung. \\
\hline 4 & Lasmini & Kristen & DsSambirejoKec. Pare \\
\hline 5 & Tumini & Islam & Ds Payaman, Kec. Plemahan \\
\hline 6 & Moch. Khoiri & Islam & Ds. Gadungan, Kec. Puncu \\
\hline 7 & Tentrem U. & Islam & DsnPutuk, Ds. Banaran, Kec. Kandangan \\
\hline 8 & Ragil & Kristen & DesaSidorejo, Kec. Pare \\
\hline 9 & Abdul Fatah & Islam & DesaSebet, Kec. Plemahan \\
\hline 10 & GimanSunyoto & Hindu & DsnPutuk, Ds. Banaran, Kec. Kandangan \\
\hline 11 & Ngatemi & Islam & DesaTiruKidul, Kec. Gurah \\
\hline 12 & Sundari & Islam & DsnSelorejo, DesaBlaru, Kec. Badas \\
\hline 13 & Supardi & Kristen & Ds Sambirejo, ,Kec. Pare. \\
\hline 14 & Karimah & Islam & Ds. Gempolan, Kec. Gurah. \\
\hline 15 & Suwarno & Islam & DsnBancangan, Ds. Blaru, Kec. Badas. \\
\hline 18 & Nuryanto & Islam & Ds. TiruKidul, Kec. Gurah. \\
\hline 19 & Sudarno & Islam & DsnSumberBahagia, Ds. Gadungan, Kec. Puncu. \\
\hline 20 & Mardi & Hindu & Ds Putuk, Kec. Kandangan \\
\hline 21 & Juni & Islam & Ds. Ngreco, Kec. Kandat. \\
\hline 22 & Maimunah & Islam & Ds. Kepuh, Kec. Papar. \\
\hline 23 & Maksum & Islam & Ds. Ngampel, Kec. Papar. \\
\hline 24 & Sriyono & Islam & Ds. Mojosari, Kec. Kras. \\
\hline 25 & SitiMariyanah & Islam & Ds. Tegalan, Kec. Kandat. \\
\hline 26 & Meseni & Islam & Ds. Pojok, Kec. Wates. \\
\hline 27 & Haryanto & Katolik & Ds. SidorejoKec. Pare. \\
\hline 28 & SlametMulyadi & Islam & Ds. Sekoto, KecBadas. \\
\hline 29 & DediAndika & Islam & Ds. Blabak, Kec. Kandat. \\
\hline 30 & Yatini & Islam & Ds. Sebet, Kec. Plemahan. \\
\hline 31 & Ikhwan & Islam & Ds. Ngletih, Kec. Kandat. \\
\hline 32 & Dasuki & Islam & DsnSumoroto, Ds. Blabak, Kec. Kandat. \\
\hline
\end{tabular}




\begin{tabular}{|llll|}
\hline 33 & AstutiRahayu & Islam & DsnNgampel, Ds. Selodono, Kec. Ringinrejo. \\
\hline 34 & Sugianto & Islam & Ds. Kepuh, Kec. Papar. \\
\hline 35 & Sri Bambang & Islam & Ds. Sidorejo, Kec. Pare. \\
\hline 36 & Mujito & Islam & Ds. Gadungan, Kec. Wates. \\
\hline 37 & Khomsiyah & Islam & Ds. Tawangrejo, Kec. Nagdiluwih. \\
\hline 38 & Sidiq & Islam & Ds. SumberGayam, Kec. Kepung. \\
\hline 39 & Juwet & Islam & Ds. Maron, Kec. Banyakan. \\
\hline 40 & Misri & Islam & Ds. Kacangan, Ke. Kandangan \\
\hline 41 & Sulastri & Katolik & Ds. Bringin, Kec. Pare \\
\hline 42 & Antiyah & Islam & Ds. Tegalan, Kec. Kandat \\
\hline 43 & UmiMardiyah & Islam & Ds. Tegalan, Kec. Kandat \\
\hline 44 & Sutikno & Islam & Ds. Jajar, Kec. Wates \\
\hline 45 & Rudi & Kristen & Ds. Tegowangi, Kec. Plemahan \\
\hline 46 & Elok & Islam & Ds. Karangasem, Kec. Badas \\
\hline 47 & Tri Wahyuni & Islam & Ds. KawedusanKec.Plosoklaten \\
\hline 48 & Jamiati & Islam & Ds. Ngampel, Kec. Papar \\
\hline 49 & Tugiyono & Islam & Ds. Kepuh, Kec. Papar \\
\hline 50 & Pani & Islam & Dsn. Kunden, Ds. Bringin, Kec. Badas \\
\hline 51 & Sarmuji & Kristen & Ds. Tegowangi, Kec. Plemahan \\
\hline 52 & Nurali & Islam & Dsn. Kayen, Ds. Ringinpitu, Kec. Plemahan. \\
\hline 53 & Purwanto & Islam & Ds. Asmorobangun, Kec. Puncu \\
\hline 54 & Paenah & Islam & Ds. Tulungrejo, Pare \\
\hline 55 & Yusuf & Islam & Ds. Tegalan, Kec. Kandat \\
\hline & & & \\
\hline
\end{tabular}

The data above showed that among 55 beneficiaries of the housing construction programs, 10 persons are non-Muslims. During the livable house construction process, ShiddiqiyahTariqa never invited the house owner and the people around to be a member of ShiddiqiyahTariqa. They never make an issue the belief and the course of the house owner. This describes that the ShiddiqiyahTariqaaccepts pluralism in society [13].

The process of grounding pluralism spirits becomes urgent given that Indonesian culturally and geographically is varied as marked by its different islands, customs, religions, and cultures [2]. The pluralism that impacts on understanding and inclusive attitude needs an action that does not prioritize Islam only but also struggles for heterogeneity for the interests of society in general [14]. ShiddiqiyahTariqa has applied this concept. When the construction process runs for a month, they have to sacrifice their work and family times for the success of the program. They do not only struggle for themselves and their family, but also for the public. This is based on the belief that the fulfillment of society and other people's needs will give a positive effect on ShiddiqiyahTariqa [15]. The process above also has a positive impact on deradicalization. For almost a month, they got involved in the livable house construction process during which they interact with any kind of people. Indirectly, they are incused to have a good personality, i.e. tolerant, inclusive, not fanatical, and moderate.

Tolerance accelerates the deradicalization process. Agus Surya Bakti said that the role of society could be channeled through local wisdom, which is a strong fortification for 
preventing radicalism. As a multicultural country, we do have a lot of potentials to prevent radicalism, one of them is through local wisdom that has been present for long in each society [7].

Radicalism popularly refers to various forms of political extremism or efforts to change the social order in a drastic and extreme way. Even though violence war a powerful device to build a nation in the history of human civilization, history proved that no religion justifies or even promotes violence. Like Christianity, Islam also is a reformist, not an expansionist, religion [16].

As an example, the Christian history was marked by the cross transformation from the symbol of holy sacrifice and suffering to the war flag. Constantine, the first Christian emperor claimed that he got an inspiration from a whisper "with the cross you will win". This inspiration is considered war justification in the name of religion [16]. In the history of Muslims, the same thing has happened. The concept of jihad was used as a slogan and justification to wage war in the name of religion. The fourth Khalifah, Umar bin Khattab, who was aware of the danger of misusing the concept of jihad for material interests and the oppression of the weak, had banned military expedition at one time [16].

Pluralism is an attitude of recognizing differences must be the basis for inclusive religious attitudes. As Muhammad Arkoun revealed, Muslims should avoid excessive hegemony that can marginalize other groups or communities. It is important for a Muslim to maintain morality in life because exclusivism and Muslim domination over non-Muslims can endanger religious pluralism and national unity so that it is difficult to be justified by the principle of Islamic universalism itself. The superior dominance of Muslims will bring injustice to marginalizing non-Muslim societies [2]. The livable housing construction program reflects the absence of hegemony. In terms of bargaining power, ShiddiqiyahTariqa is in a higher position than the poor whose houses are reconstructed. However, this condition is not a reason for them to withdraw or force the poor to become members of ShiddiqiyahTariqa.

\section{Conclusion}

The philanthropic activities of the livable construction house program for the poor have been able to foster pluralism attitudes and deradicalization among the members of the ShiddiqiyahTariqa. In the reconstruction process, they got involved with many people from different religions and religious sects. This process renders the members of ShiddiqiyahTariqathe capacity to understand and manage heterogeneous societies. A higher structural position does not make them claim hegemony. However, this attitude is still internal in the sense that this research only observed pluralism as practiced in the internal of ShiddiqiyahTariqa. Further research can be focused on the extent to which pluralism attitudes and behaviors are able to give color to a wider community.

\section{References}

[1] L. Bagus, Kamus Filsafat. Jakarta: Gramedia, 2000.

[2] S. Bakri, Pilar Islam Bagi Pluralisme Modern. Solo: Tiga Serangkai, 2003.

[3] B. M. Rachman, Reorientasi Pembahauan Islam. Malang: Madina.

[4] Kuntowijaya, Paradigma Islam: Interpretasi untuk Aksi. Bandung: Mizan, 1999. 
[5] P. Budi, "Peran Pondok Pesantren dalam Deradikalisasi Paham dan Gerakan Islam Radikal (Studi Pondok Pesantren Riyadlatul Ulum Batanghari Lampung Timur)," Fikri, vol. 2, 2017.

[6] O. Nurul, "Filantropi Dakwah dan Kaum Minoritas di Indonesia," vol. 1, 2017.

[7] A. Bakti, Darurat Terorisme: Kebijakan Pencegahan, Perlindungan, dan Deradikalisasi. Daulat Press, 2014.

[8] N. Amania, "PERAN LEMBAGA PENDIDIKAN WAKAF DALAM MEMBENTUK KARAKTER BERTOLERANSI," Stain Kudus, no. Zakat dan Waqaf.

[9] J. Creswell, Qualitatif Inquiry Dan Research Design, III. California: SAGE, 2015.

[10] J. Creswell, Research Design, Qualitative, Quantitative, and Mixed Methods Approaches, III. California: SAGE, 2009.

[11] H. Tohari, Islam Dan Urusan Kemanusiaan. Jakarta: Serambi Ilmu Semesta, 2015.

[12] A. Engineer, Islam Dan Pembebasan. Yogyakarta: LKiS, 1993.

[13] Nurhadi, Wawancarar dengan Pengurus Jamaah Shiddiqiyah. 2019.

[14] N. Madjid, Dialog Keterbukaan. Jakarta: Paramadina, 1998.

[15] A. Fauzi, Wawancara Denagan Relawan. 2019.

[16] A. Shihab, Islam Inklusif, Menuju Sikap Terbuka Dalam Beragama. Bandung: Mizan, 1999. 